\title{
PREDICTION OF STREAM FLOWS IN MAI- NEFHI RESERVOIR BY HYDROLOGIC MODELLING USING SOIL AND WATER ASSESSMENT TOOL (SWAT)
}

\author{
Dr. Kahsay Negusse Zeraebruk \\ Assistant Professor, Department of Civil Engineering, \\ Mai Nefhi College of Engineering and Technology, \\ Asmara, Eritrea
}

\begin{abstract}
The yield of any surface water source mainly depends on inflow of the reservoir and that impacts the availability of drinking water for the cities in future. Assessment of long-term impacts of projected changes in reservoir level is critical to address the challenges in protecting surface water reserves. In other words, to deal with water management issues, one must analyse and quantify changes of flow taking place within the area and causes. Obviously, this analysis must be carried out on a watershed basis because all these processes are taking place within individual micro watersheds. The development of remote sensing and GIS techniques has allowed the use of spatially and physically based hydrologic models to simulate as simply and realistically as possible the functioning of watershed systems. The main objective of this study is to model the hydrology of the Mai-Nefhi catchment area in order to establish the water balance and monthly stream inflow to the Mai-Nefhi dam. The Mai-Nefhi reservoir is one of the main sources of water to Asmara, the capital city of Eritrea. The Soil and Water Assessment Tool (SWAT) interface which works in the ArcGIS software platform was used to delineate the basin and sub-basins and estimate the streamflow. The calibration was carried out successfully, for the period 1972-1980, using SWAT-CUP SUFI-2 (Sequential Uncertainty Fitting version 2) program for a combined optimization-uncertainty analysis. The validation of the model was checked for the period 19811986 and the values of streamflow are nearly equal to the observed streamflow data. The hydrological analysis shows that the resulting changes on the annual streamflow volume is not significant because of the prevailing short rainy months.
\end{abstract}

Keywords: Hydrologic Simulation Modelling, Water Balance, Calibration, Mai-Nefhi Watershed.

\author{
G. Siva Sankar, \\ Lecturer, Department of Civil Engineering, \\ Mai Nefhi College of Engineering and Technology, \\ Asmara, Eritrea
}

\section{INTRODUCTION}

Water is the most important natural resource for human kind and development. Global advances in economies and living standards have resulted in a growing dependency on water resources [4] Daniel et al., (2011). Water crisis has become the critical point in limiting cities' economic and social development nowadays [5] Du, Xu, Wang, \& Yang, (2011). Rapid economic growth, decentralization, privatization, and related socio-cultural changes are leading to the emergence of a complex decision making environment. New concepts and approaches are needed to find constructive solutions to water resource allocation issues in urban ecosystem. [5] Du et al., (2011).

Well over half of the world's potable water supply is extracted from rivers, either directly or from reservoirs [2] Barnett, Adam, \& Lettenmaier, (2005). Understanding the hydrological aspect of the water balance of a basin, especially the amount of flow in rivers (streamflow), which involves complex processes and interactions at the surface, subsurface, and their interface, is the most important aspect in water resources development and management programs. The role of hydrology for sustainable development and global welfare is crucial as hydrology should provide the necessary knowledge and understanding of the operation of hydrological processes and their spatial and temporal variability [12] Uhlenbrook, (2006). The major aspect of these programs is to understand how much water is or could be available in the area under study as a source of water for different purposes.

Major hydrological processes can be quantified with the help of water balance equations. The components of water balance of a basin are influenced by climate, the physical characteristics of the watershed such as morphology, land-use and soil. Understanding the relationship between these physical parameters and hydrological components are very essential for any water resources development related work. Simulations of the water balance dynamics of catchments are needed for addressing a number of engineering and environmental problems such as assessing anthropogenic effects on water 


\section{International Journal of Engineering Applied Sciences and Technology, 2020 \\ Vol. 4, Issue 10, ISSN No. 2455-2143, Pages 27-33 \\ Published Online February 2020 in IJEAST (http://www.ijeast.com)}

quantity and quality, estimating design values and streamflow forecasting [8] Merz \& Blöschl, (2004). Hydrologic modelling can play an important role as a decision support tool in water resources development and management. The great challenge in hydrology today is the development of models that can give reliable predictions of runoff from catchments, especially from un-gauged ones, and yet to be flexible enough to be used to evaluate different management scenarios [3] Birhanu, (2009). However, it has been much difficult in developing countries where inadequacy of appropriate tools and personnel to develop and maintain water resources model are evident, but also their catchments experiences insufficient data to build, calibrate and validate models.

The hydrologic simulation model, Soil and Water Assessment Tool (SWAT) was chosen for this study because it includes many useful components and functions for simulating the water balance and the other watershed processes such as water quality, climate change, crop growth, and land management practices. Furthermore, the SWAT model was adopted in this study because it is known for its efficiency and reliability and has already been tested in several studies carried out on catchments areas around East Africa such as Ethiopia and Kenya with very good and encouraging outcomes [7] Mango et al., (2011), [10] Setegn, Srinivasan, \&Dargahi, (2008) ; [11] Tewodros Taffese (2013)

\section{MATERIALS AND METHODS}

\section{A. Description of the Study Area}

Asmara is the capital city of Eritrea and the administrative center of the Central Region. Asmara is located at an average elevation of $2325 \mathrm{~m}$ above mean sea level in the central highlands of Eritrea (Fig. 1). Recent population record shows that the current population of Asmara, including the villages around it, is estimated to be around 500,000.

The major source of water supply for Asmara is surface water collected during the rainy months of summer. The runoff created from the rainfall over the drainage areas joins streams and rivers and finally collected into storage reservoirs by dams constructed across the rivers.

The major surface reservoirs that currently used as a source of water for municipal water in Asmara are, Mai-Nefhi, Toker, Adi-Sheka and Mai-Serwa reservoirs (Table 1 and Fig. 2).

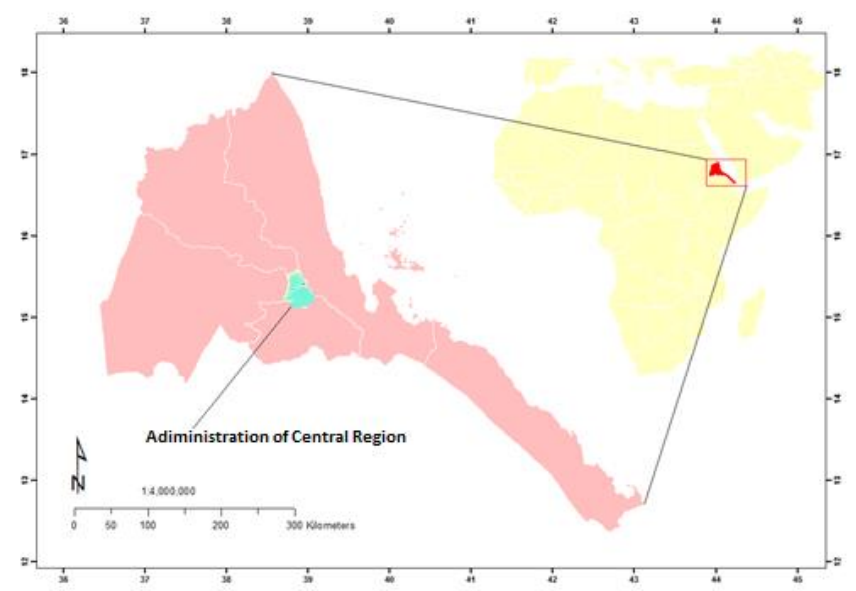

Fig. 1. Location of Eritrea and Administration of Central Region.

The Mai-Nefhi watershed covers areas mostly to the south east of the Central Region. The water from this catchment area is collected at Mai-Nefhi dam located at a distance of about 25 $\mathrm{km}$ south east of Asmara. It has the largest capacity and it is one of the major sources of water supply to the city (Fig. 2). The watershed covers an area close to $95 \mathrm{~km} 2$ with elevations ranging from $2200 \mathrm{~m}$ to $2350 \mathrm{~m}$.

Table 1: Major reservoirs around Asmara developed for water supply

\begin{tabular}{|l|c|c|}
\hline $\begin{array}{l}\text { Name of } \\
\text { Reservoir }\end{array}$ & $\begin{array}{l}\text { Catchment } \\
\text { Area } \\
\left(\mathbf{K m}^{\mathbf{2}}\right)\end{array}$ & $\begin{array}{l}\text { Storage } \\
\left.\text { capacity } \mathbf{( x 1 0}^{\mathbf{6}}\right) \\
\mathbf{m}^{\mathbf{3}}\end{array}$ \\
\hline Mai Nefhi & 95 & 26 \\
\hline Toker & 67 & 16 \\
\hline Adi Sheka & 33 & 5 \\
\hline Mai Serwa & 11 & 2.5 \\
\hline StrettaVadeto & 15 & 1.8 \\
\hline
\end{tabular}

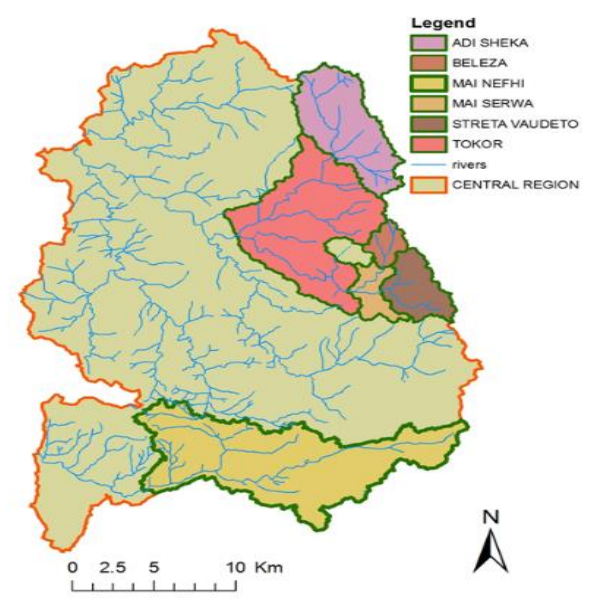

Fig. 2. Catchment areas in Central Region developed for Asmara water supply. 


\section{International Journal of Engineering Applied Sciences and Technology, 2020 \\ Vol. 4, Issue 10, ISSN No. 2455-2143, Pages 27-33 \\ Published Online February 2020 in IJEAST (http://www.ijeast.com)}

The climate of the region is characterised as semiarid with average yearly precipitations of $450-600 \mathrm{~mm}$ and annual average air temperature varying between $11^{\circ} \mathrm{C}$ for minimum temperatures and $24^{\circ} \mathrm{C}$ for maximum temperatures.

\section{B. Hydrologic Modelling}

In this study, ArcSWAT graphical user interface was used to manipulate and execute the major functions of SWAT (Soil Water Assessment Tool) model from the ArcGIS tool. The aim is to set up and run the SWAT model on Mai-Nefhi catchment with the existing data to illustrate the possibility and the adaptability of the model to simulate the streamflow of the river.

\section{Swat model}

SWAT was developed to predict the impact of land management practices on water, sediment and agricultural chemical yields in large complex watersheds with varying land use and management conditions over a long periods of time [9] S. L. Netsch, J. G. Arnold, J. R. Kiniry, (2009). It is physically based and semi-distributed model developed for continuous simulation on a daily time step. SWAT allows simulating the major watershed processes and has the capacity to simulate physical processes such as stream flow, sediment transport and agrochemical yields. Digital elevation model (DEM), weather data, soil data and land use/land cover data are the most important data input for the setup of the SWAT model and for the simulation of the hydrological components [6] Fiseha \& Setegn, (2012). One of the main goals of SWAT model is to predict the impact of land management practices on water quantity and quality over long periods of time for large complex watersheds that have varying soils, land use and management practices [9] S. L. Netsch, J. G. Arnold, J. R. Kiniry, (2009). SWAT can be broken into two major components: a land phase, and a routing phase. The land phase of the model distributes the incoming precipitation between the possible hydrologic pathways (all units are mm per unit area) through the water balance equation. No matter what type of problem studied with SWAT, water balance is the driving force behind everything that happens in the watershed [9] S. L. Netsch, J. G. Arnold, J. R. Kiniry, (2009). The hydrologic cycle is simulated by SWAT model based on the following water balance equation.

$S W_{t}=S W_{o}+\sum_{i=1}^{t} R_{d a y}-Q_{\text {surf }}-E_{a}-w_{\text {seep }}-Q_{g w}$

where: $t$ is the time in days, $S W t$ the final soil water content $(\mathrm{mm})$, SWo the initial soil water content $(\mathrm{mm})$, Rday is amount of precipitation on day $\mathrm{i}(\mathrm{mm})$, Qsurf is the amount of surface runoff on day $\mathrm{i}(\mathrm{mm}), \mathrm{Ea}$ is the amount of evapotranspiration on day $\mathrm{i}(\mathrm{mm})$, Wseep is the amount of water entering the vadose zone from the soil profile on day $\mathrm{i}(\mathrm{mm}), \mathrm{Qgw}$ is the amount of return flow on day $i(\mathrm{~mm})$.

The first step in using SWAT model is to generate stream network and sub-basins within the study area and then to delineate the watershed based upon the Digital Elevation Model (DEM), which is the topographic characteristic of the area, and the outlet selected by the user.
The next step is the creation of homogeneous areas called hydrologic response units (HRUs) that GIS derives from the overlaying of slope, land use and soil layers. This is basically dividing the basins into smaller pieces each of which has a particular soil/land-use/slope range combination.

\section{Digital Elevation Model (DEM)}

The DEM used to delineate the study area was obtained from Department of Water Resources of the Ministry of Land Water and Environment (MoLWE) of Eritrea, which has a spatial resolution of $30 \mathrm{~m}$ covering the whole of Eritrea. The topographic parameters such as terrain slope, channel slope or reach length were also generated from the DEM. (Fig. 3).

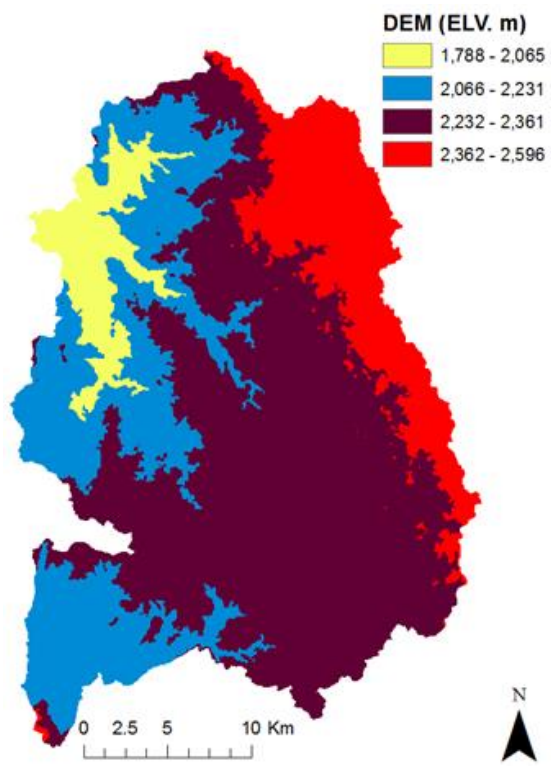

Fig. 3. Digital Elevation Model (DEM) of Central Regional Administration

\section{E. Land use/Land cover}

Land use and management is an important factor affecting different processes in the watershed, such as surface runoff, erosion, recharge and evapotranspiration [7] Mango et al., (2011). It is one of the key input parameters required in SWAT for HRU-delineation which determines how specific types of land cover will respond to changes in hydrology.

Updated and processed spatial land use layers for the study area were obtained from Water Resources Department of MoLWE extracted from Food and Agriculture Organization (FAO). Land use classification (FOA) for Central Regionand Mai_Nefhi watershed is shown in Fig. 4.

For Mai-Nefhi catchment area, five major classes were identified. The dominant categories are agricultural land (49\%), grazing land $(36 \%)$ and built-up $(12 \%)$ while plantation and water body account for about $3 \%$. 

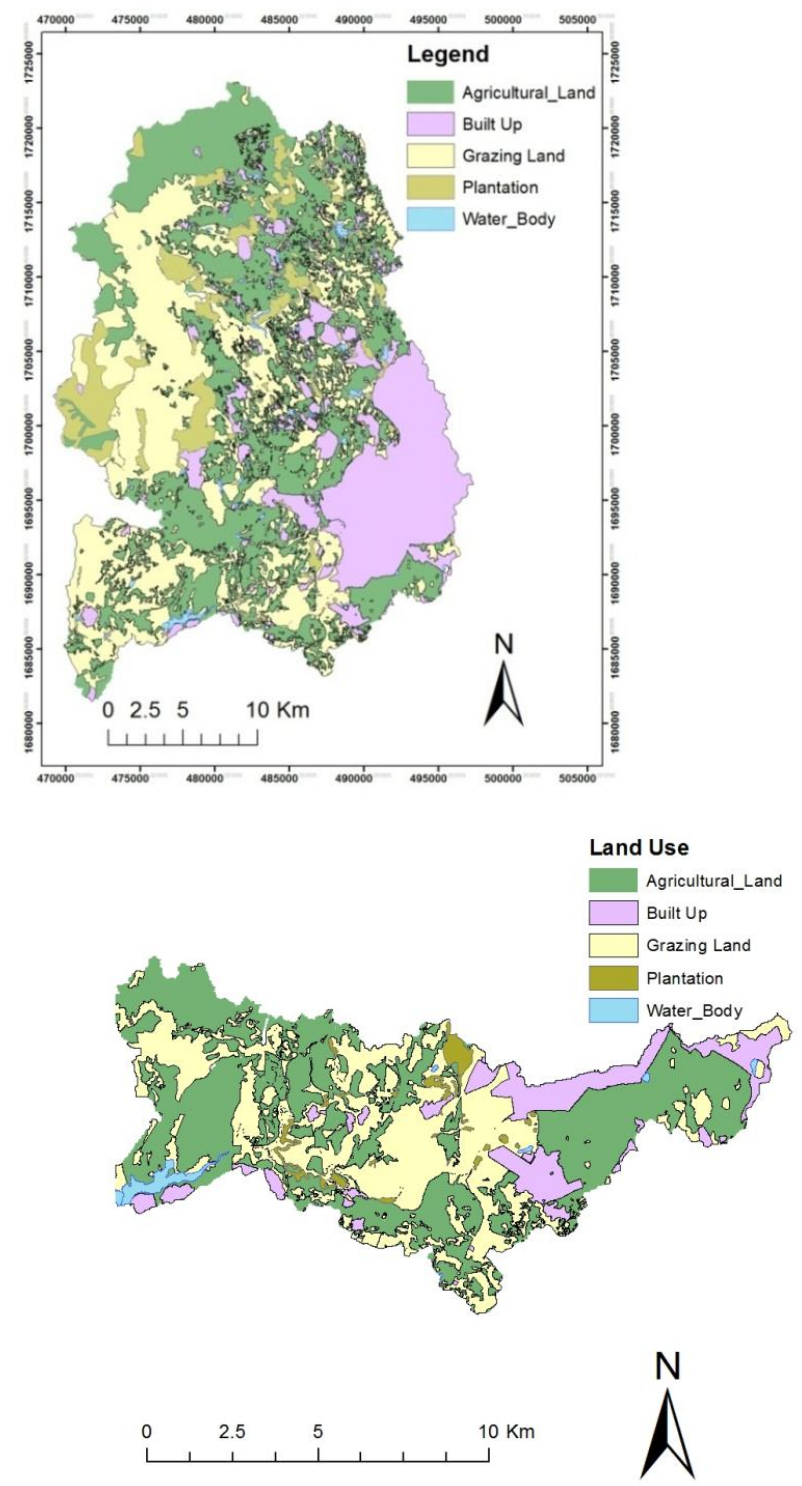

Fig. 4. Land use classification (FOA) (a) Central Region (b) Mai_Nefhi watershed

\section{F. Soil data}

The soil map shown in Fig. 5, was extracted from the Digital soil map of Eritrea developed by Food and Agriculture Organization of the United Nations (FAO-UN) soil and terrain database for East Africa (FAO 1996). Updated and processed spatial soil data layers were also collected from Water Resources Department of MoLWE.

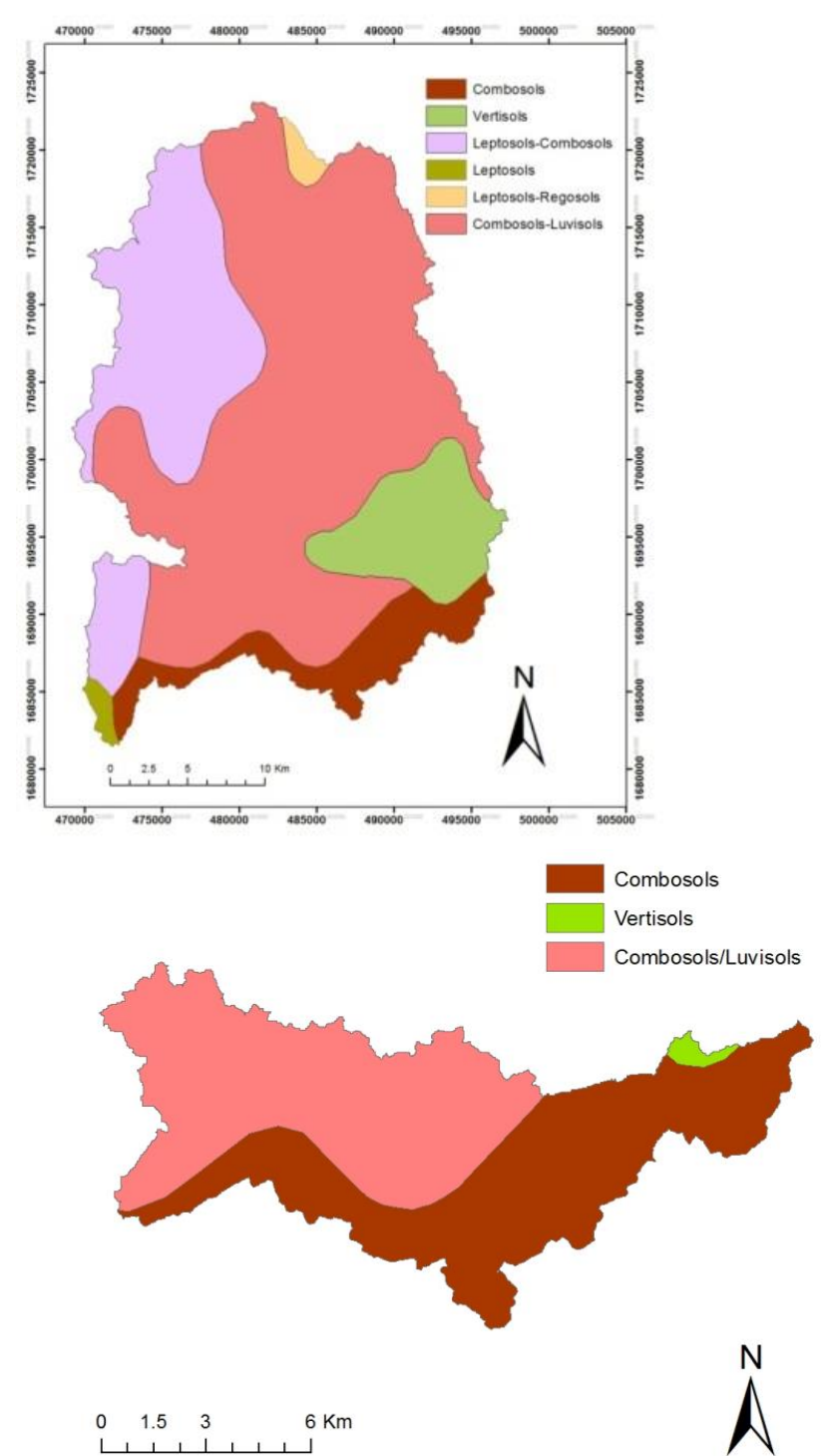

Fig. 5. Soil classification (a) Administration of Central region (b) Main-Nefhi watershed

\section{SWAT MODEL APPLICATION}

\section{A. Model Setup}

The model parameterisation for Mai-Nefhi catchment area was derived using the ArcMap GIS interface for SWAT2009, which provides a graphical support for the disaggregation scheme and thus facilitates the data handling. First, the whole watershed was delineated using the DEM and with an outlet at the location of the dam. In the next step, land uses and soils were characterized and overlaid to the watershed. This resulted in subdivision of the watershed into 21 sub-basins (Fig. 6). 


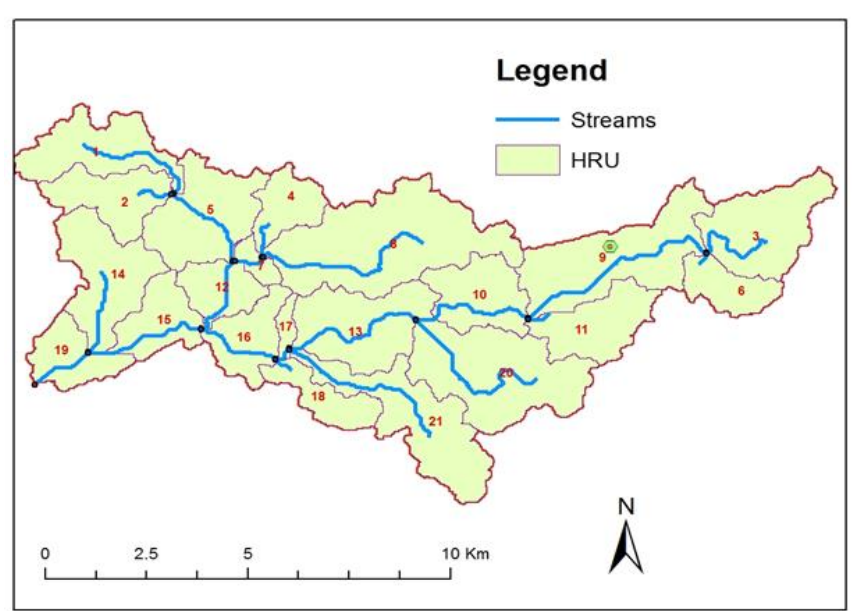

Fig. 6. Delineation of sub-basins for Mai-Nefhi catchment area

\section{B. Sensitivity Analysis}

The parameter sensitivity analysis was done using the ArcSWAT interface for the whole catchment area. The sensitivity analysis method used in ArcSWAT interface combines the Latin Hypercube simulation and the One-factorAt-a-Time sampling. Twenty-six hydrological parameters were tested for sensitivity analysis for the simulation of the stream flow in the study area. Here, we used the default lower and upper bound parameter values. The ten most sensitive parameters resulted from the sensitivity analysis are shown in Table 2.

Table 2: Best parameters ranked from sensitivity analysis

\begin{tabular}{|c|c|l|}
\hline Rank & Parameter & \multicolumn{1}{|c|}{ Description } \\
\hline 1 & SOL_Z & \multicolumn{1}{|c|}{ Soil depth (mm) } \\
\hline 2 & CN2 & $\begin{array}{l}\text { initial SCS runoff curve } \\
\text { number for moisture } \\
\text { condition II }\end{array}$ \\
\hline 3 & GWQMN & $\begin{array}{l}\text { Threshold water depth in the } \\
\text { shallow aquifer for flow (mm) }\end{array}$ \\
\hline 4 & ESCO & $\begin{array}{l}\text { soil evaporation } \\
\text { compensation factor }\end{array}$ \\
\hline 5 & SOL_AWC & $\begin{array}{l}\text { Available water capacity (mm } \\
\text { H2O) }\end{array}$ \\
\hline 7 & BLAI & $\begin{array}{l}\text { Maximum potential leaf area } \\
\text { index }\end{array}$ \\
\hline 8 & CANMX & $\begin{array}{l}\text { Maximum canopy storage } \\
\text { (mm) }\end{array}$ \\
\hline 9 & REVAPMN & $\begin{array}{l}\text { Base flow alpha factor (days) } \\
\text { (mm) }\end{array}$ \\
\hline 10 & GW_REVAP & $\begin{array}{l}\text { Groundwater } \\
\text { coefficient }\end{array}$ \\
\hline
\end{tabular}

\section{Model calibration and validation procedure}

The estimated average monthly observed volume inflow to the Mai-Nefhi reservoir during the period 1972-1980, has been used for calibration of the model. The calibration was carried out using SWAT-CUP SUFI-2 (Sequential Uncertainty Fitting version 2) program for a combined optimization-uncertainty analysis. SUFI-2 is a multi-site, semi-automated global search procedure. In SUFI-2, parameter uncertainty accounts for all sources of uncertainties such as uncertainty in driving variables (e.g., rainfall), conceptual model, parameters, and measured data [1] Abbaspour, (2012). The validation has been done thereafter to evaluate the performance of the model with calibrated parameters to simulate the hydrological functioning of the watershed over another time period that has not been used in the calibration phase.

The temporal daily data used to set up the SWAT model in Mai-Nefhi covers 15 years (1972- 1986). The first nine years (1972-1980) were used to simulate the watershed with SWAT and calibrate with SWAT-CUP. The next four years (19811984) for model validation.

Statistical measures such as the Nat-Sutcliffe Efficiency (NSE) and the Correlation Coefficient (R2) were used to describe and compare the observed and simulated data sets.

$$
\begin{aligned}
N S E & =1-\left[\frac{\sum_{i=1}^{n}\left(Y_{i}^{o b s}-Y_{i}^{s i m}\right)^{2}}{\sum_{i=1}^{n}\left(Y_{i}^{o b s}-Y^{\text {mean }}\right)^{2}}\right] \\
R^{2} & =\frac{\sqrt{\sum_{i=1}^{n}\left(Y_{i}^{o b s}-Y_{i}^{s i m}\right)^{2}}}{\sum_{i=1}^{n}\left(Y_{i}^{o b s}-Y^{\text {mean }}\right)^{2}}
\end{aligned}
$$

Where $\boldsymbol{Y}_{\boldsymbol{i}}{ }^{\boldsymbol{o b s}}$ is the $\boldsymbol{i} \boldsymbol{i} \boldsymbol{h}$ observed streamflow, $\boldsymbol{Y}_{\boldsymbol{i}}^{\text {sim }}$ the $\boldsymbol{i t h}$ simulated value, $\boldsymbol{Y}^{\text {mean }}$ the mean of observed data and $\boldsymbol{n}$ is the total number of observations.

\section{RESUlTS AND DISCUSSIONS}

\section{A. Hydrologic model calibration and validation}

The calibration approach adopted for modelling the MaiNefhi River watershed involved systematic adjustment of parameters which were generally applied throughout the basin. The results of the hydrologic simulation showed that the most sensitive parameters for hydrological modelling of upstream watershed of Mai-Nefhi dam are SOL_Z, CN2, GWQMN, ESCO and SOL_AWC. This result is in agreement with those found by many similar studies, confirming that these five parameters are the crucial sensitive parameters for water balance and stream flow. 


\section{International Journal of Engineering Applied Sciences and Technology, 2020 \\ Vol. 4, Issue 10, ISSN No. 2455-2143, Pages 27-33 \\ Published Online February 2020 in IJEAST (http://www.ijeast.com)}

The statistical analysis shows that for the calibration period the model efficiency (NSE) was 0.78 , while the $\mathrm{R}^{2}$ was 0.96 for a monthly time interval. The monthly values of NSE and the $\mathrm{R}^{2}$ for the validation period were 0.58 and 0.88 respectively (Table $3)$.

Table 3 Statistical evaluation of simulated versus observed streamflow data

\begin{tabular}{lcc}
\hline Coefficient & $\begin{array}{c}\text { Calibration } \\
\text { Period }\end{array}$ & $\begin{array}{c}\text { Validation } \\
\text { Period }\end{array}$ \\
\hline $\mathrm{R}^{2}$ & 0.96 & 0.88 \\
$\mathrm{NSE}$ & 0.78 & 0.58 \\
\hline
\end{tabular}

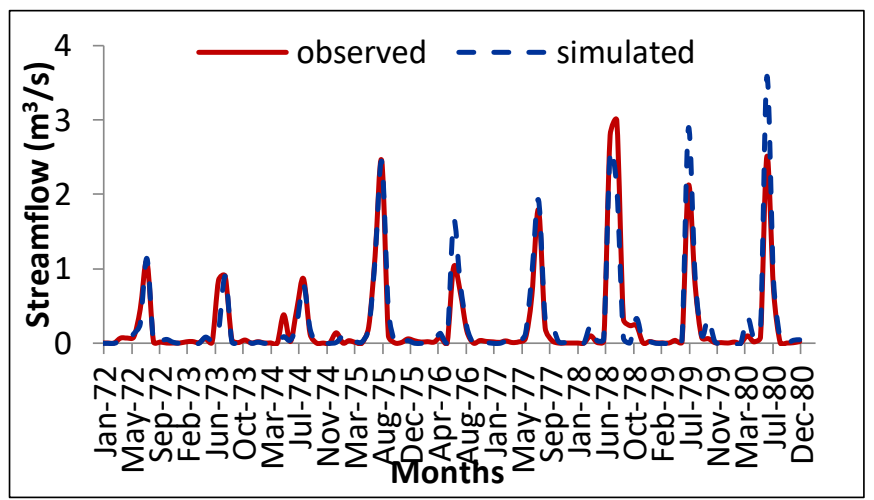

Fig.7. Comparison of monthly observed and calibrated streamflow (1972-1980).

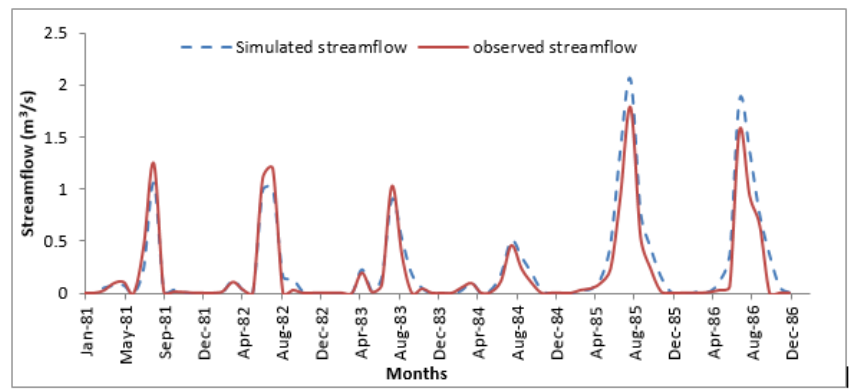

Fig.8. Comparison of monthly observed and simulated streamflow for the validation period (1981-1986)

Therefore, according to model evaluation a criterion introduced by model calibration is satisfactory. Monthly average observed and simulated flows for the calibration period 19721980 and for the validation period 1981-1986 are presented in Figure 7 and Figure 8 respectively.

\section{CONCLUSION}

The hydrologic model developed by SWAT interface has shown better performance in predicting stream flows in MaiNefhi catchment with the observed values. The model exhibits correlation coefficient $\mathrm{R}^{2}$ more than 0.9 in calibration period that shows the simulated values are accorded with observed stream flow data for the validation period. variations in future Stream flows can be quantified and analyzed for the reasons to change in hydrological cycle. The simulation model and the output of this study are expected to be used by Asmara water supply managers, policy makers and decision makers as vital tools for planning, management and development of water resources of the region.

\section{REFERENCES}

[1] Abbaspour, K. C., Faramarzi, M., \& Rouholahnejad, E. (2010) "Hydrological Modeling of Alberta Using Swat Model". North, 1-83.

[2] Barnett, T. P., Adam, J. C., \& Lettenmaier, D. P. (2005). Potential impacts of a warming climate on water availability in snow-dominated regions. Nature, 438(7066), 303-309. doi:10.1038/nature04141

[3] Birhanu, B. Z. (2009) "Hydrological modeling of the Kihansi river catchment in South Central Tanzania using SWAT model" 1(1), 1-10.

[4] Daniel, E. B., Camp, J. V, Leboeuf, E. J., Penrod, J. R., Dobbins, J. P., \& Abkowitz, M. D. (2011) "Watershed Modeling and its Applications: A State-of-the-Art Review" The Open Hydology, 26-50.

[5] Du, J., Xu, L., Wang, S., \& Yang, F. (2011) "Simulation of Urban Ecological Water Demand Using Multiobjective System Dynamic Model” International Journal of Chemical Engineering and Applications, 2(2), 143146. doi:10.7763/IJCEA.2011.V2.92

[6] Fiseha, B., \& Setegn, S. (2012) "Hydrological analysis of the Upper Tiber River Basin, Central Italy: a watershed modelling approach" doi:10.1002/hyp

[7] Mango, L. M., Melesse, a. M., McClain, M. E., Gann, D., \& Setegn, S. G. (2011). Land use and climate change impacts on the hydrology of the upper Mara River Basin, Kenya: Results of a modeling study to support better resource management. Hydrology and Earth System Sciences, 15(7), 2245-2258. doi:10.5194/hess-15-22452011

[8] Merz, R., \& Blöschl, G. (2004) "Regionalisation of catchment model parameters" Journal of Hydrology, 287(1-4), 95-123. doi:10.1016/j.jhydrol.2003.09.028

[9] S. L. Netsch, J. G. Arnold, J. R. Kiniry, J. R. W. (2009) "Soil \& Water Assessment Tool Theoretical Documentation Version"

[10] Setegn, S. G., Srinivasan, R., \& Dargahi, B. (2008). "Hydrological Modelling in the Lake Tana Basin, Ethiopia Using SWAT Model". The Open Hydrology Journal,2(1),49-62.doi:10.2174/1874378100802010049

[11] Tewodros Taffese, B. Z. (2013) "Hydrological modelling of a catchment using the SWAT model in the upper Blue Nile basin of Ethiopia Hydrological modelling of a catchment using the SWAT model in the upper Blue Nile basin of Ethiopi", proceedings of nile basin 
International Journal of Engineering Applied Sciences and Technology, 2020

Vol. 4, Issue 10, ISSN No. 2455-2143, Pages 27-33

Published Online February 2020 in IJEAST (http://www.ijeast.com)

development challenge science meeting, Addis ababa , 910 july.

[12] Uhlenbrook, S. (2006) "Catchment hydrology-a science in which all processes are preferential" Hydrological Processes, 3585(August), 3581-3585. doi:10.1002/hyp 